\title{
Klasifikasi Penyakit Tiroid Menggunakan Algoritma C4.5 (Studi Kasus : Rumah Sakit Umum Daerah (RSUD) Hasanuddin Damrah Manna)
}

\author{
Devi Sartika ${ }^{1}$, Yupianti ${ }^{2}$ \\ 1,2 Informatika, Fakultas Ilmu Komputer, Universitas Dehasen Bengkulu \\ ${ }_{1}$ Devisartika@unived.ac.id, 2 Yupiantiprana@gmail.com
}

\begin{abstract}
ABSTRAK
Tiroid adalah merupakan salah satu bagian tubuh yang sangat penting bagi manusia, tiroid berbentuk kelenjar dan letaknya di bawah jakun pada leher. Penyakit gondok disebabkan oleh gangguan pada kelenjar tiroid. Berdasarkan data histori penderita yang disebabkan oleh kelenjar tiroid dapat dibuat rekomendasi prediksi penyakit tiroid yang membantu tenaga kesehatan. Klasifikasi merupakan salah satu teknik dari data mining yang dapat digunakan untuk membuat prediksi. Klasifikasi dapat dilakukan dengan decision tree salah satunya dengan algoritma C4.5. Penelitian ini bertujuan membuat klasifikasi data penyakait yang disebabkan oleh gejala kelenjar tiroid dan menerapkannya dalam pembangunan sistem. Implementasi sistem menggunakan bahasa pemrograman Visual Basic 2010 dan metode penelitian yang digunakan pada penelitian ini adalah metode waterfall. metode waterfall mampu melakukan analisa kebutuhan yang digunakan untuk mengetahui dari kelemahan sistem yang lama, kemudian membuat desain dari rancangan tersebut dan dilanjutkan dengan pembuatan rancangan sistem baru. Hasil dari penelitian adalah menghasilkan rule yang dapat membantu tenaga kesehatan di RSUD Hasanuddin Damrah Manna dalam mendiagnosa penyakit yang disebabkan oleh kelenjar tiroid.
\end{abstract}

Kata kunci : Data Mining, Decision Tree, C4.5, Kelenjar Tiroid

\section{PENDAHULUAN}

Tiroid adalah merupakan salah satu bagian tubuh yang sangat penting bagi manusia, tiroid berbentuk kelenjar dan letaknya di bawah jakun pada leher. Tiroid merupakan kelenjar endokrin terbesar dalam tubuh berbentuk kupu-kupu. Fungsi kelenjar tiroid adalah menghasilkan hormon tiroid yang berguna untuk menjaga metabolisme tubuh. Untuk meningkatkan jumlah oksigen pada sel dan rangsangan jaringan tubuh dalam menghasilkan protein. Penyakit gondok disebabkan oleh gangguan pada kelenjar tiroid. Ada dua jenis gangguan tiroid yang dapat muncul yaitu hipertiroid dan hypotiroid. Hipertirod adalah kondisi dimana kelenjar tersebut bekerja secara berlebihan, sedangkan hipotiroid adalah kebalikannya.

Beberapa teknik data mining telah diterapkan pada dunia kesehatan seperti pada kasus klasifikasi dan data prediktif. Beberapa teknik data mining yang telah digunakan pada bidang kesehatan seperti mendeteksi penyakit hipertensi pada kehamilan dirumah sakit. Untuk menganalisa data dalam jumlah yang besar yang tersimpan pada suatu database, diperlukan teknik data mining.

Data mining adalah suatu proses untuk memperoleh informasi penting yang sangat berguna dari informasi yang sebelumnya tidak diketahui dan pengetahuan yang diperoleh informasi yang

\section{Article History:}

Received: August 30th 2019: Accepted: January, 12th 2020

ISSN: $2502-5325$ (Online) Terakreditasi Peringkat 3 oleh Kementerian Riset, Teknologi dan Pendidikan Tinggi (ARJUNA), berdasarkan Keputusan Direktur Jenderal Penguatan Riset dan Pengembangan No: 23/E/KPT/2019 tanggal 8 Agustus 2019 berharga dan dapat dimengerti dari sebuah data (Sartika \& Jumadi, 2019). Untuk bisa mendapatkan informasi dari sekumpulan database yang besar diperlukan proses data mining seperti klasifikasi. Klasifikasi atau taksonomi adalah proses menempatkan suatu objek atau konsep kedalam satu set kategori berdasarkan objek atau konsep yang bersangkutan (Andriani, 2013). Metode klasifikasi digunakan untuk membantu dalam memahami pengelompokkan data. Klasifikasi sendiri merupakan cabang dari discovery data mining.

Algoritma C4.5 adalah salah satu metode klasifikasi dari data mining yang digunakan untuk membangun pohon keputusan (decision tree). Algoritma ini mempunyai input berupa training sample dan sample. Training Sample berupa data contoh yang akan digunakan untuk membangun sebuah pohon (tree) yang telah diuji kebenarannya. Sedangkan Sample merupakan field-field data yang nantinya akan digunakan sebagai parameter dalam melakukan klasifikasi.

Berdasarkan hal yang telah dijabarkan di atas maka penulis melakukan penelitain yang dituangkan dalam pembuatan aplikasi Klasifikasi Penderita Penyakit Tiroid.

Adapun batasan masalah pada penelitian ini adalah attribut yang digunakan sebanyak 24 (dua puluh empat) gejala.

Cite this as: Sartika, D. Yupianti, Y. (2020). Klasifikasi Penyakit Tiroid Meng-
gunakan Algoritma C4.5 (Studi Kasus : Rumah Sakit Umum Daerah (RSUD) Hasanuddin Damrah Manna). Rekayasa, 13(1), 71-76. doi: https://doi.org/10.21107/rekayasa.v13i1.5912 


\section{METODE PENELITIAN}

\section{Knowledge Discovery In Database (KDD)}

Knowledge Discovery in Database (KDD) merupakan metode untuk memperoleh pengetahuan dari database yang ada. Dalam database terdapat tabel - tabel yang saling berhubungan / berelasi. Hasil pengetahuan yang diperoleh dalam proses tersebut dapat digunakan sebagai basis pengetahuan (knowledge base) untuk keperluan pengambilan keputusan(Yuli, 2017).

Proses KDD secara garis besar dapat dijelaskan sebagai berikut :

1. Data Selection

2. Pre-processing / cleaning

3. Transformation

4. Data Mining

5. Interpretation / Evaluation

\section{Data Mining}

Data mining adalah proses mencari pola atau informasi menarik dalam data terpilih dengan menggunakan tekik atau metode tertentu. Teknik, metode atau algoritma data mining sangat bervariasi. Pemilihan metode atau algoritma yang tepat sangat bergantung pada tujuan dan proses Knowledge Discovery in Database (KDD)(Muzakir \& Wulandari, 2016)

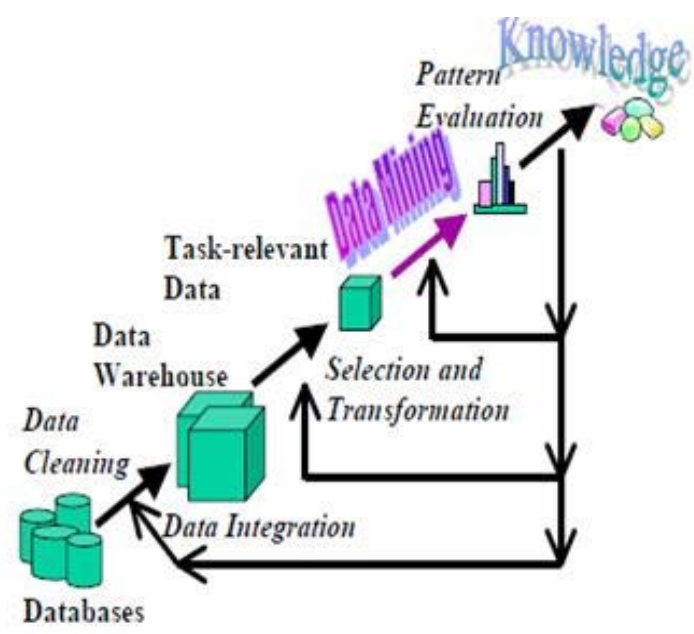

Gambar 1. Proses Data Mining

\section{Klasifikasi}

Klasifikasi pertama kali diterapkan pada bidang tanaman yang mengklasifikasi suatu spesies tertentu, seperti yang dilakukan oleh Carolus von Linne (atau dikenal dengan nama Carolus Linnaeus) yang pertama kali mengklasifikasi spesies berdasarkan karakteristik fisik. Selanjutnya dia dikenal sebagai bapak klasifikasi.
Dalam klasifikasi terdapat target variabel kategori. Metode-metode atau model-model yang telah dikembangkan oleh periset untuk menyelesaikan kasus klasifikasi antara lain :

1. Pohon Keputusan

2. Pengklasifikasian bayes

3. Jaringan saraf tiruan

4. Analisa statistik

5. Algoritma genetik

6. Rought set

7. Pengklasifikasi K-Nearest Neighbour

8. Metode berbasis aturan

9. Memori based reasoning

10. Support Vector Machine (SVM)

\section{Decision Tree (Pohon Keputusan)}

Sebuah decision tree adalah sebuah struktur yang dapat digunakan untuk membagi kumpulan data yang besar menjadi himpunan-himpunan record yang lebih kecil dengan menerapkan serangkaian aturan keputusan. Pada decision tree setiap simpul daun menandai label kelas. Simpul yang bukan simpul akhir terdiri dari akar dan simpul internal yang terdiri dari kondisi tes atribut pada sebagian record yang mempunyai karakteristik yang berbeda. Simpul akar dan simpul internal ditandai dengan bentuk oval dan simpul daun ditandai dengan bentuk segi empat. (Muzakir \& Wulandari, 2016). Berikut adalah struktur decision tree seperti yang ditunjukkan pada gambar berikut ini

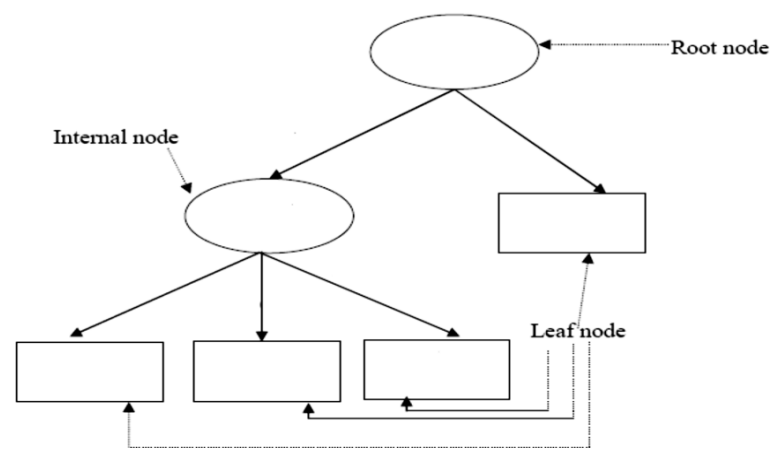

Gambar 2. Struktur Decision Tree

\section{Algoritma C4.5}

Algoritma C4.5 adalah salah satu algoritma yang digunakan dalam decison tree. Algoritma C4.5 merupakan pengembangan dari algoritma ID3 (Iterative Dichotomiser 3) yang dikembangkan oleh J.Ross Quinlan(Muzakir \& Wulandari, 2016).

Algoritma data mining C4.5 merupakan salah satu algoritma yang digunakan untuk melakukan klasifikasi atau segmentasi atau pengelompokan dan bersifat prediktif. Dasar algoritma adalah pembentukan pohon keputusan (decision tree). Cabangcabang pohon keputusan merupakan pertanyaan klasifikasi dan daun-daunnya merupakan kelaskelas atau segmen-segmennya. 
Secara umum, algoritma C4.5 untuk membangun sebuah pohon keputusan adalah sebagai berikut :

1. Hitung jumlah data, jumlah data berdasarkan anggota atribut hasil dengan syarat tertentu.

2. Pilih atribut sebagai Node

3. Buat cabang untuk tiap-tiap anggota dari Node

4. Periksa nilai entropy dari anggota node yang ada bernilai Nol. Jika ada, tentukan daun yang terbentuk. Jika seluruh nilai entropy anggota node adalah nol, maka proses pun berhenti

5. Jika ada anggota node yang memiliki entropy lebih besar dari no, ulangi lagi proses dari awal dengan node sebagai syarat sampai semua anggota dari node bernilai nol.

Node adalah atribut yang mempunyai nilai gain tertinggi dari atribut-atribut yang ada. Untuk menghitung nilai gain suatu atribut digunakan rumus sebagai berikut:

Gain $=(S . A)=\operatorname{Entropy}(S)-\sum_{i=1}^{n} \frac{A_{1}}{S} * \operatorname{Entropy}\left(A_{1}\right)$

Keterangan :
$S$ : Kasus
A : Atribut
$\mathrm{n}$ : Jumlah partisi atribut $A$
$A_{i}$ : Jumlah kasus pada partisi ke-i
$\mathrm{S}$ : Jumlah kasus

Sedangkan untuk menghitung nilai entropy dapat dilihat pada persamaan berikut :

$$
\operatorname{Entropy}(S)=\sum_{i=1}^{n}-p i * \log _{2} p i
$$

Keterangan :

$$
\begin{array}{ll}
\mathrm{S} & : \text { Himpunan kasus } \\
\mathrm{n} & : \text { Jumlah partisi } \mathrm{S} \\
P_{i} & : \text { Proporsi dari } S_{i} \text { ke } S
\end{array}
$$

\section{Proses Klasifikasi dengan C4.5}

Pada tahap ini akan dibuat pengetahuan, yang akan dijelaskan pada tabel penyakit yang disebabkan oleh kelenjar tiroid, tabel keputusan, rule-rule, dan pohon keputusan, yang akan dijabarkan secara rinci pada tabel 1 dan tabel 2 .

Tabel 1 Tabel Penyakit

\begin{tabular}{ll}
\hline Kode Penyakit & Nama Penyakit \\
\hline P01 & Gondok \\
P02 & Hipoteroid \\
P03 & Hiperteroid \\
\hline
\end{tabular}

Dari tabel analisa perhitungan tersebut diatas, akan diperhitungkan nilai entropy dan gaindari masing-masing gejala. Berikut perhitungan nilai entropy dan nilai gain node pertama:

\section{Rancangan Sistem}

\section{Diagram Konteks}

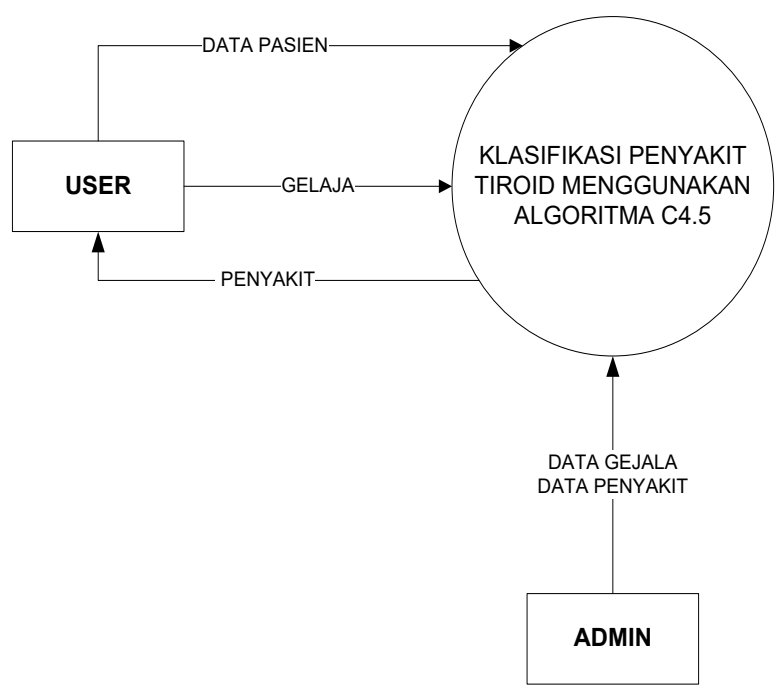

Gambar 3 Diagram Konteks

Table 2 Gejala Penyakit

\begin{tabular}{ll}
\hline Kode Gejala & Nama Gejala \\
\hline G01 & Nafsu makan berkurang \\
G03 & Mulut terasa tegang dan nyeri \\
G04 & Sering mual dan muntah \\
G05 & Suhu badan tinggi \\
G06 & Telinga berdengung \\
G07 & Kelelahan \\
G08 & Tidak tahan dingin \\
G09 & Depresi \\
G10 & Rambut dan kulit kering dan kasar \\
G11 & Nafsu makan berkurang \\
G12 & Berat badan naik \\
G13 & Nyeri otot \\
G14 & Wajah membengkak \\
G15 & Suara kasar dan lambat \\
G16 & Sendi kaku \\
G17 & Sembelit (BAB tidak teratur) \\
G18 & Ngantuk yang berlebihan \\
G19 & Konsentrasi menurun \\
G20 & Pembengkakan di pangkal leher \\
G21 & Tidak tahan panas \\
G22 & Gemetaran \\
G23 & Denyut jantung yang cepat \\
G24 & Konsentrasi yang berkurang \\
\hline
\end{tabular}




\section{Entity Relationship Diagram (ERD)}

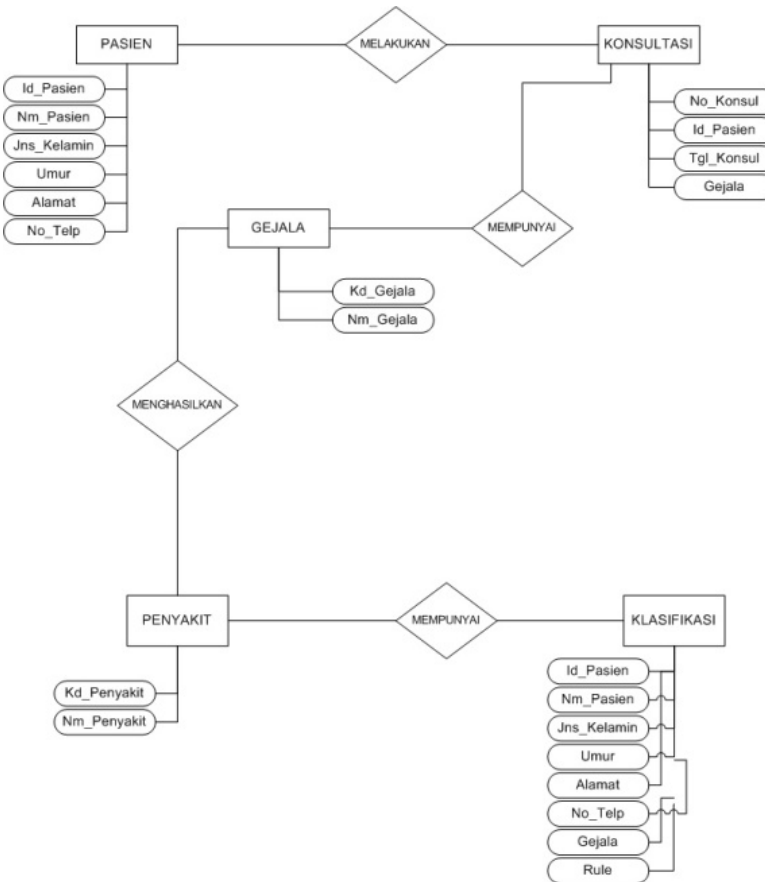

Gambar 4 ERD

\section{Struktur Menu}

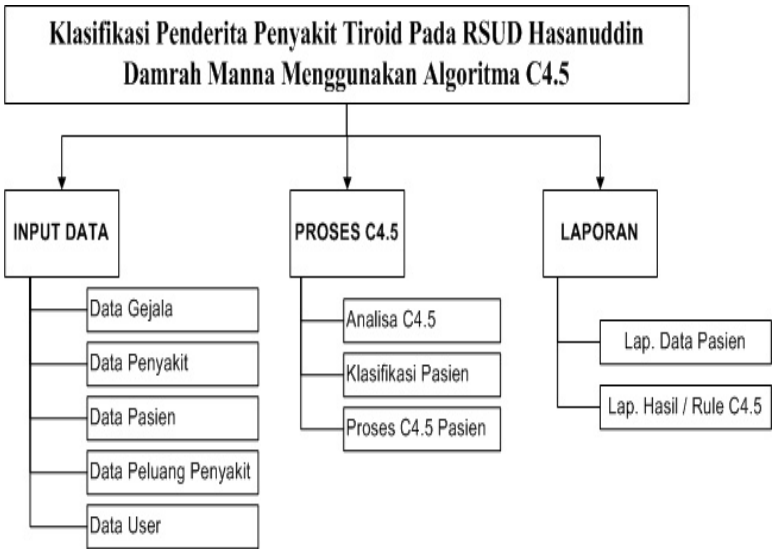

Gambar 5 Struktur Menu

\section{HASIL DAN PEMBAHASAN}

Implementasi aplikasi klasifikasi penyakit tiroid untuk pasien pada RSUD Hasanuddin Damrah Manna berdasarkan gejala yang dialami penderita mempunyai beberapa interface (antar muka) antara lain adalah sebagai berikut :

\section{Form Input Data Gejala}

Sub menu input data gejala merupakan form untuk melakukan entri data gejala yang terdapat pada aplikasi ini :

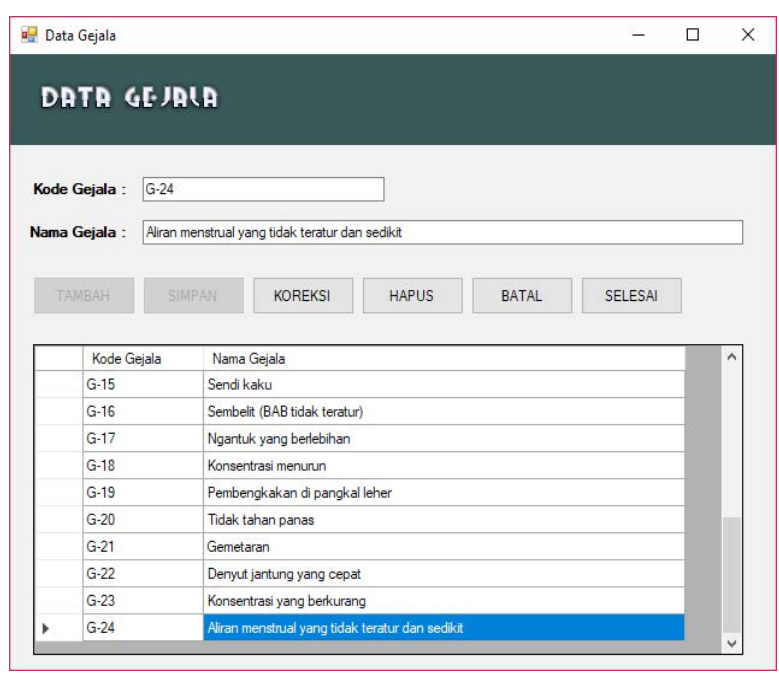

Gambar 6 Form Input Data Gejala

\section{Form Input Data Penyakit}

Sub menu input data penyakit merupakan form untuk melakukan entri data penyakit. Input data penyakit berfungsi sebagai tatap muka (interface) guna melakukan penambahan data, perbaikan data, pembatalan data, dan penghapusan data penyakit

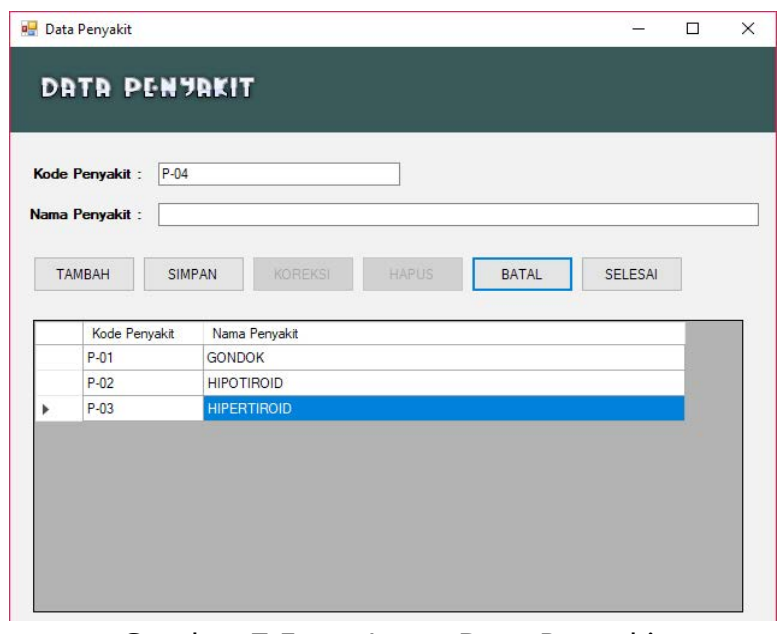

Gambar 7 Form Input Data Penyakit

\section{Form Input Data Pasien}

Sub menu input data pasien merupakan form untuk melakukan entri data pasien. Input data pasien berfungsi sebagai tatap muka (interface) guna melakukan penambahan data, perbaikan data, pembatalan data, dan penghapusan data pasien 


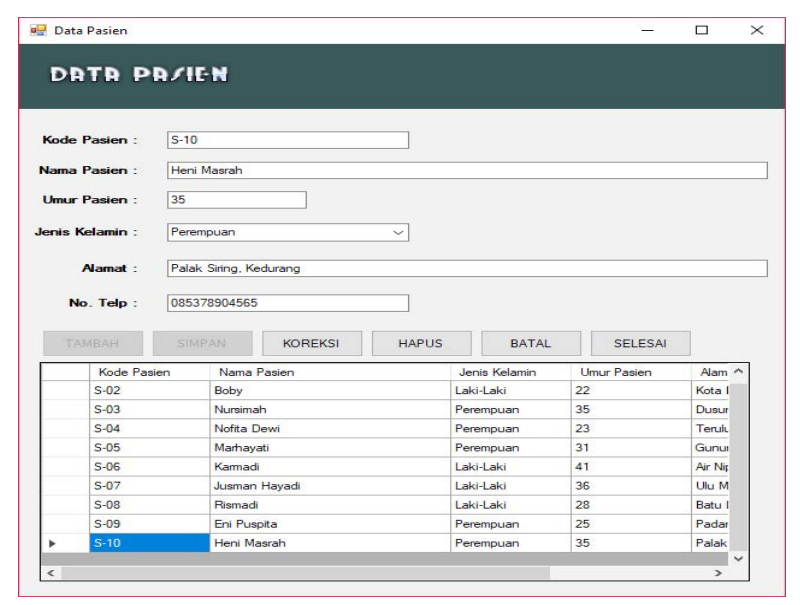

Gambar 8 Form Input Data Pasien

\section{Form Input Data Peluang Penyakit}

Form input data peluang penyakit merupakan interface yang berfungsi untuk mengetahui hubungan gejala dengan penyakit

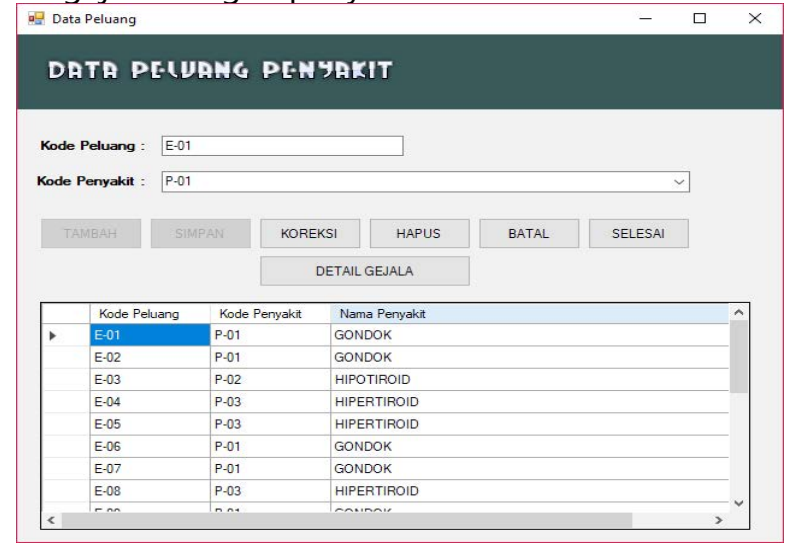

Gambar 9 Form Input Data Peluang Penyakit

Pada interface input data peluang penyakit terdapat tombol "Detail Gejala". Tombol "Detail Gejala" ini berfungsi untuk menampilkan interface detail data penyakit terhadap gejala

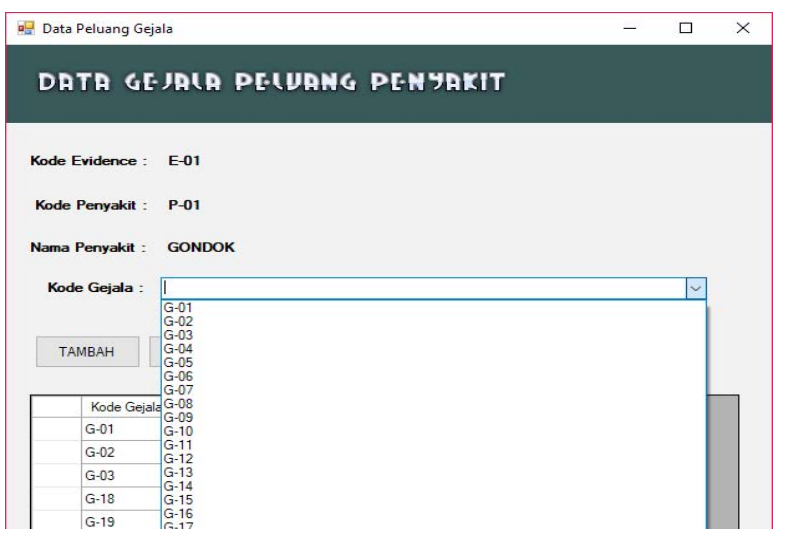

Gambar 10. Form Data Detail Penyakit Terhadap Gejala

\section{Form Proses Klasifikasi Penyakit Pasien}

Menu proses klasifikasi pasien merupakan interface yang berfungsi untuk mengetahui penyakit yang diderita oleh pasien berdasarkan dengan gejala yang dipilih atau dialami oleh pasien

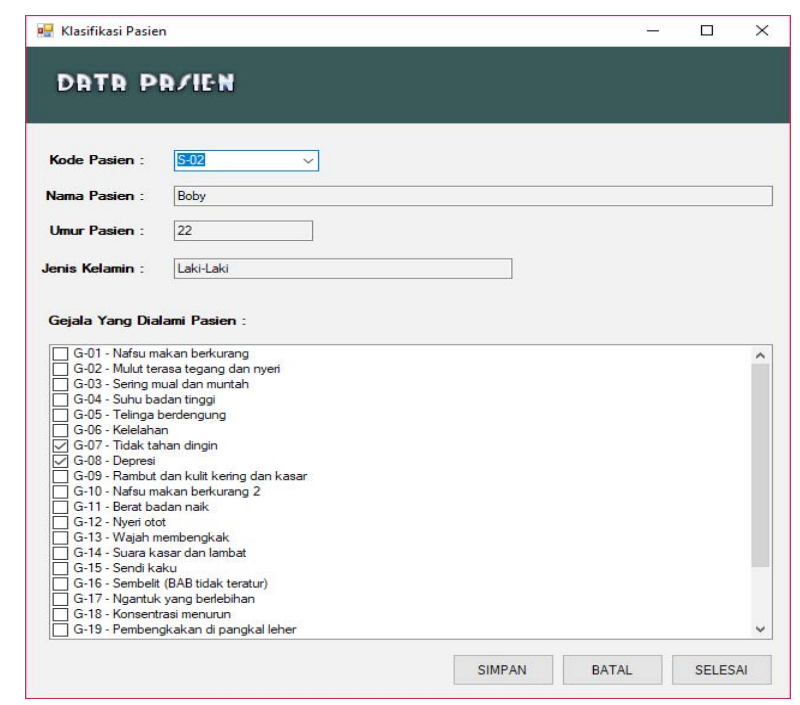

Gambar 11 Form Proses Klasifikasi Penyakit Pasien

\section{Form Proses C4.5 Pasien}

Form proses $C 4.5$ pasien merupakan interface untuk memproses data gejala yang telah dipilih pada interface klasifikasi pasien agar mendapatkan hasil penyakit apa yang diderita oleh pasien.
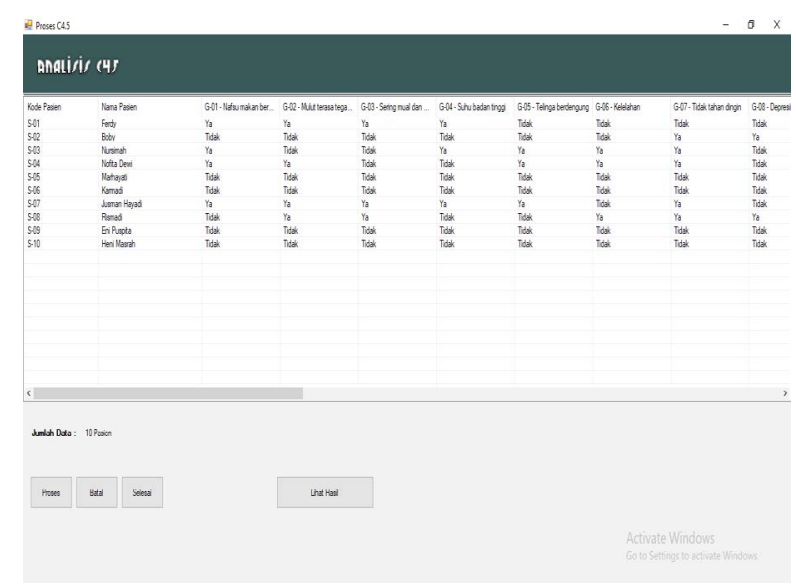

Gambar 12 Form Proses C4.5 Pasien

Pada gambar interface diatas dapat dilihat bahwa semua data pasien yang telah melakukan diagnosa penyakit berhasil direkam oleh sistem yang kemudian akan diproses dengan menggunakan algoritma C4.5 dengan cara meng-klik tombol "Proses" maka akan tampil hasil seperti terlihat seperti gambar berikut ini : 


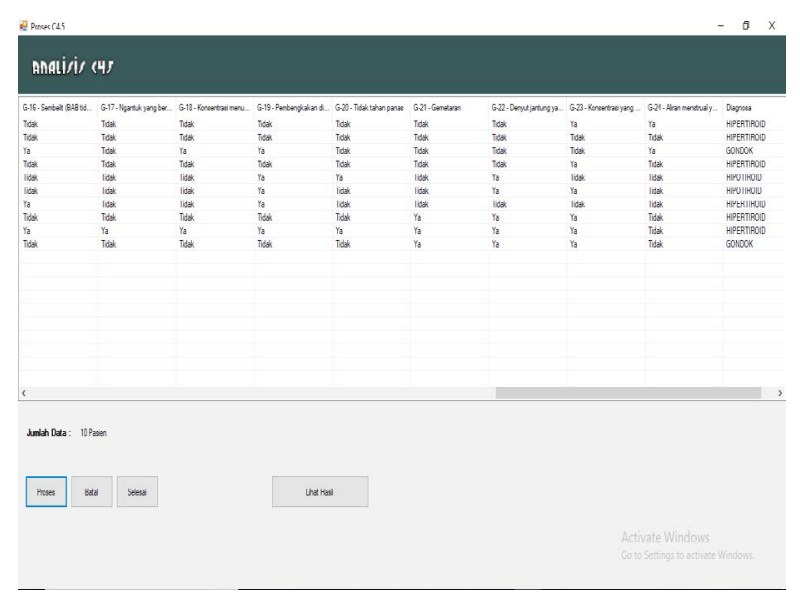

Gambar 13 Form Hasil Proses Diagnosa Pasien

\section{KESIMPULAN}

Berikut kesimpulan yang diambil berdasarkan pembahasan sistem klasifikasi penyakit tiroid yang telah dibangun menggunakan algoritma C4.5 pada RSUD Hasanuddin Damrah Manna, yaitu :

1. Sistem Klasifikasi penyakit tiroid menggunakan algoritma C4.5 yang dibuat telah sesuai dengan tahapan atau urutan proses yang semestinya.

2. Dengan adanya sistem ini, maka RSUD Hasanuddin Damrah Manna dapat terbantu dalam melakukan diagnosa penyakit yang disebabkan oleh kelenjar tiroid.
3. Mempermudah menampilkan informasi diagnosa penyakit pasien berdasarkan gejala yang dialami atau yang telah dipilih di dalam sistem.

\section{DAFTAR PUSTAKA}

Andriani, A. (2013). Sistem Prediksi Penyakit Diabetes Berbasis Decision Tree. Bianglala Informatika, 1(1), 1-10.

Muzakir, A., \& Wulandari, R. A. (2016). Model Data Mining sebagai Prediksi Penyakit Hipertensi Kehamilan dengan Teknik Decision Tree. Scientific Journal of Informatics, 3(1), 19-26. https://doi.org/10.15294/sji.v3i1.4610

Sartika, D., \& Jumadi, J. (2019). Clustering Penilaian Kinerja Dosen Menggunakan Algoritma K-Means ( Studi Kasus : Universitas Dehasen Bengkulu ). Sainteks, (978-602-52720-1-1), 703-709.

Suyanto, D. (2017). Data Mining Untuk Klasifikasi dan Klasterisasi Data. Bandung: Informatika Bandung

Yakub. (2012). Pengantar Sistem Informasi. Yogyakarta: Graha Ilmu.

Yuli, M. (2017). Jurnal Edik Informatika Data Mining: Klasifikasi Menggunakan Algoritma C4 . 5 Data mining merupakan bagian dari tahapan proses Knowledge Discovery in Database (KDD). Jurnal Edik Informatika. Jurnal Edik Informatika, 2(2), 213-219. 